\title{
Biodecolorization of methyl orange by mixed cultures of brown-rot fungus Daedalea dickinsii and bacterium Pseudomonas aeruginosa
}

\author{
ADI SETYO PURNOMO`, MITHA OCDYANI MAWADDAH \\ Department of Chemistry, Faculty of Science, Institut Teknologi Sepuluh Nopember. Jl. Raya ITS, Sukolilo, Surabaya 60111, East Java, Indonesia. \\ Tel.: +62-31-594 3353, Fax.: +62-31-592 8314, •email: adi_setyo@chem.its.ac.id
}

Manuscript received: 27 February 2020. Revision accepted: 29 April 2020.

\begin{abstract}
Purnomo AS, Mawaddah MO. 2020. Biodecolorization of methyl orange by mixed cultures of brown-rot fungus Daedalea dickinsii and bacterium Pseudomonas aeruginosa. Biodiversitas 21: 2297-2302. This study investigated on the decolorization of methyl orange (MO) by mixed cultures of brown-rot fungus (BRF) Daedalea dickinsii and bacterium Pseudomonas aeruginosa. P. aeruginosa was added into $D$. dickinsii culture at $2,4,6,8,10 \mathrm{~mL}\left(1 \mathrm{~mL}=5.05 \times 10^{12} \mathrm{CFU}\right)$. All of mixed cultures had ability to decolorize MO (final concentration $100 \mathrm{mg} / \mathrm{L}$ ) in potato dextrose broth (PDB) medium for 7 days incubation. The addition of $4 \mathrm{~mL}$ of $P$. aeruginosa showed the highest MO biodecolorization approximately $97,99 \%$, while by D. dickinsii only was $67,54 \%$. $\mathrm{C}_{15} \mathrm{H}_{19} \mathrm{~N}_{3} \mathrm{O}_{5} \mathrm{~S} ; \mathrm{C}_{16} \mathrm{H}_{21} \mathrm{~N}_{3} \mathrm{O}_{5} \mathrm{~S}$; $\mathrm{C}_{17} \mathrm{H}_{23} \mathrm{~N}_{3} \mathrm{O}_{6} \mathrm{~S}$; and $\mathrm{C}_{15} \mathrm{H}_{19} \mathrm{~N}_{3} \mathrm{O}_{6} \mathrm{~S}$ were identified as $\mathrm{MO}$ metabolites. This study indicated that mixed cultures of $D$. dickinsii and $P$. aeruginosa have great potential for high efficiency, fast and cheap dye wastewater treatment.
\end{abstract}

Keyword: Biodecolorization, Daedalea dickinsii, methyl orange, Pseudomonas aeruginosa

\section{INTRODUCTION}

The activities of the textile industry cannot be separated from the dyed process and produce waste residue dyes that are discharged into the environment. Wastewater containing textile dyes can be toxic, carcinogenic and may even cause genetic and harmful mutations for aquatic organisms and humans. One of azo's textile dyes is methyl orange (MO), which is a water-soluble dye, used as a textile dye, and as an indicator $\mathrm{pH}$ (Ljubas et al. 2015). The release of industrial pollutants has become a major concern for human health and the environment, which dyes are amongst the major contributors to environmental pollution. Dyes are used extensively to alter the color characteristics as well as enhance the appearance of various products. However, as most natural dyes are unstable, thus synthetic dyes have emerged as an essential alternative (El Nemr 2012). In the staining process, $15 \%$ of the MO dyes are not absorbed, released, and flowed in wastewater streams. Even at very low concentrations, MO dye in water is very visible. From an ecological perspective, the presence of azo dyes in textile effluents is highly undesirable as azo dye effluents are heavily colored, concentrated with salt, and have high biological oxygen demand (BOD) and chemical oxygen demand (COD). BOD and COD values in some textile effluents were found to be in the range of 220-490 $\mathrm{mg} / \mathrm{L}$ and $180-940 \mathrm{mg} / \mathrm{L}$ respectively (Chiong et al. 2016). The contamination may inhibit the penetration of light into the water and may invade the process of photosynthesis by aquatic organisms. Therefore, decolorization is a major problem in wastewater treatment from industry (Liu et al. 2012).

Conventional treatment of dye waste has been widely applied such as chemically, physically, and biologically. Over the past decade, researchers have focused more on biological treatment because it is cheap and environmentally friendly. Among the many biological agents involved in bioremediation, bacteria, and fungi are important agents (Ali and Ahmed 2010). The dye degradation of MO using the fungus has been much studied. The commonly used fungus is a type of white-rot fungus, although many other types of fungus are reported to degrade azo-colored dyes such as MO (Bumpus 2004). Only a few studies reported degradation or decolorization using brown-rot fungi (BRF) as reported by Ali and Hameed (2010). Aspergillus flavus SA2 can degrade dye Red Acid 151 by $67 \%$ (initial concentration of $20 \mathrm{mg} / \mathrm{L}$ ). While the fungus Penicillium spp. and Alternaria spp. SA4 can degrade orange II dye by $34 \%$ and $57 \%$ (initial concentration $20 \mathrm{mg} / \mathrm{L}$; Bumpus 2004). Since BRF does not have ligninolytic enzymes, it has been proposed that they use hydroxyl radicals produced via the Fenton reaction for the degradation of wood components (Purnomo et al. 2010c, 2011a). In BRF, extracellular Fenton-type mechanisms have been reported to be involved in degradation of several xenobiotic compounds, including the fluoroquinolone antibiotics enrofloxacin and ciprofloxacin, polyethylene glycol, chlorophenol, 2,4,6trinitrotoluene (Purnomo et al. 2011b), aldrin, dieldrin (Purnomo et al. 2017a; Purnomo 2017), heptachlor, heptachlor epoxide (Purnomo et al. 2013; 2014) and methylene blue dye (Rizqi and Purnomo 2017). Degradation of MO by brown-rot fungus Daedalea dickinsii fungi was evaluated in PDB (Potato Dextrose Broth) at a concentration of MO $75 \mathrm{mg} / \mathrm{L}$ of $97.56 \%$ within 14 days incubation (Purnomo et al. 2019b). Although D. dickinsii had high ability to degrade MO, degradation time consumed a long time, thus culture modification is needed to improve the ability of $D$. dickinsii. 
Several studies have been reported on the use of bacterial agents to degrade azo dyes, in which two enzymes play a role in the biodecolorization of azo dyes: azoreductase and laccase (Singh et al. 2015). Pseudomonas species bacteria have been reported capable to decolorize dyes. The novel isolated laccase producing Pseudomonas stutzeri MN1 has ability to decolorize congo red and gentian violet (Kuppusamy et al. 2017). Besides, Pseudomonas aeruginosa has been reported to be able to decolorize remazol orange dye with an initial concentration of $200 \mathrm{mg} / \mathrm{L}$ within 24 hours at $82.4 \%$ (Sarayu and Sandhya 2010). P. aeruginosa is a Gram-negative, rodshaped, asporogenous, and monoflagellated bacterium. $P$. aeruginosa grows well at $25^{\circ} \mathrm{C}$ to $37^{\circ} \mathrm{C}$, and its ability to grow at $42^{\circ} \mathrm{C}$ helps distinguish it from many other Pseudomonas species. This suggests that $P$. aeruginosa can be used as biodecolorization agent. Some studies suggest that mixed cultures can improve the ability of culture degradation. The addition of $P$. aeruginosa has been reported enhance DDT degradation by Pleurotus ostreatus (Purnomo et al. 2017), and Fomitopsis pinicola (Sariwati and Purnomo 2018). Besides, mixed cultures between $D$. dickinsii and $P$. aeruginosa have been used as DDT degradation agents, in which the addition of $10 \mathrm{~mL}(1 \mathrm{~mL}$ $=1.05 \times 10^{9} \mathrm{CFU} / \mathrm{mL}$ ) of $P$. aeruginosa can degrade $100 \%$ DDT for 7 days incubation (Setyo et al. 2018). It proved that mixed cultures of $D$. dickinsii and $P$. aeruginosa is a potential degradation agent that can be used to decolorize MO dyes. Given these properties, the ability of mixed cultures of $D$. dickinsii and $P$. aeruginosa to decolorize MO was investigated and the metabolic products were identified.

\section{MATERIALS AND METHODS}

\section{Materials}

Brown-rot fungus Daedalea dickinsii NBRC 31163 and bacterium Pseudomonas aeruginosa NBRC 3009 were a collection from Microbial Chemistry laboratory of Department of Chemistry, Institut Teknologi Sepuluh Nopember (ITS), Surabaya, Indonesia. Methyl orange (MO) textile dye was purchased from SAP Chemicals (96\% purity). Growth media were Nutrient Agar (NA, Merck, German), Nutrient Broth (NB, Merck, German), Potato Dextrose Broth (PDB, Himedia, India), and Potato Dextrose Agar (PDA; Merck, German). Aqua DM and ethanol $70 \%$ were purchased from PT. Sumber Ilmiah Persada Indonesia.

\section{Fungus and bacterium culture}

Stock cultures of D. dickinsii NBRC 31163 were maintained on PDA plates that had been incubated at $30^{\circ} \mathrm{C}$ in 7 days. The mycelia from the agar plate were transferred to a sterile blender cup containing $25 \mathrm{~mL}$ of sterile water and then homogenized for $30 \mathrm{sec}$. One milliliter of this homogenate was inoculated into $8 \mathrm{~mL}$ of PDB medium in a 100-mL Erlenmeyer flask. The cultures were pre-incubated statically at $30^{\circ} \mathrm{C}$ for 7 days (Purnomo et al. 2010a). Besides, Bacterium stock cultures of $P$. aeruginosa NBRC 3080 were maintained on NA that had been incubated at $37^{\circ} \mathrm{C}$. The colony was inoculated into $10 \mathrm{~mL}$ of $\mathrm{NB}$ medium in $50-\mathrm{mL}$ Falcon flasks. The cultures were preincubated at $37^{\circ} \mathrm{C}$ for 24 hours (Wahyuni et al. 2017).

\section{Biodecolorization MO by fungus Daedalea dickinsii}

After pre-cultivating for 7 days, $10 \mathrm{~mL}$ of PDB medium was added into inoculated fungus cultures (final volume 20 $\mathrm{mL}$ ), and MO (final concentration $100 \mathrm{mg} / \mathrm{L}$ ) was added to each fungus-inoculated flask. The cultures were further incubated for $7 \mathrm{~d}$ at $30^{\circ} \mathrm{C}$ (Purnomo et al. 2010b; Setyo et al. 2018).

\section{Biodecolorization MO by bacterium Pseudomonas aeruginosa}

After pre-cultivation for $24 \mathrm{~h}, P$. aeruginosa cultures were inoculated into the PDB medium at 2, 4, 6, 8 and 10 $\mathrm{mL}\left(1 \mathrm{~mL} \approx 5,05 \times 10^{12} \mathrm{CFU}\right.$, ultimate volume $\left.20 \mathrm{~mL}\right)$. Every bacterium inoculated flask was added with MO (final concentration $100 \mathrm{mg} / \mathrm{L}$ ). The cultures were cultivated for $7 \mathrm{~d}$ at $30^{\circ} \mathrm{C}$ (Sariwati et al. 2017).

\section{Biodecolorization MO by mixed cultures of Daedalea dickinsii and Pseudomonas aeruginosa}

Biodecolorization of MO by mixed cultures was performed by adding 2, 4, 6, 8 and $10 \mathrm{~mL}(1 \mathrm{~mL}=5,05 \times$ $\left.10^{12} \mathrm{CFU}\right)$ of pre-incubated bacteria into Erlenmeyer flask containing $9 \mathrm{~mL}$ of pre-incubated fungus following by addition of PDB to the total volume of $20 \mathrm{~mL}$. Each culture was added to MO (final concentration of $100 \mathrm{mg} / \mathrm{L}$ ). The culture was incubated statically for 7 days at $30^{\circ} \mathrm{C}$. The synergistic relationship of mixed cultures was expressed with Ratio Optimization (RO) that calculated as the amount of decolorization by mixed cultures per total amounts of decolorization by fungus and bacterium (Purnomo et al. 2019a).

\section{Analytical method and identification of metabolites}

After the incubation process, cultures were separated by centrifuge $(4000 \mathrm{rpm}$ for $15 \mathrm{~min})$. The resulting supernatant was measured its absorbance by a UV-Vis spectrophotometer (Purnomo et al. 2017). For abiotic control, PDB was added MO reach to $100 \mathrm{mg} / \mathrm{L}$ concentration without the addition of cultures. The percentage of $\mathrm{MO}$ decolorized was calculated by:

$\%$ decolorization $=\frac{A_{c}-A_{t}}{A_{c}} \times 100 \%$

Where: Ac is control absorbance, and At is treatment absorbance (Rizqi and Purnomo 2017).

The identification of metabolites product from MO degradation was performed by analyzing the supernatants using a liquid chromatography-time of flight mass spectrometry (LC-TOF/MS). The ionization source was ionizing electrospray (ESI) with a mass range of 50-1000. The gradient elution method was used with flow rate of 0.2 $\mathrm{mL} / \mathrm{min}$ in the first three minutes and the next seven minutes using flow rate of $0.4 \mathrm{~mL} / \mathrm{min}$. The phase of motion was used methanol and water with a ratio of 99:1 in the initial three minutes and 61:39 for the remaining seven minutes. The column was Acclaim TM RSC 120 C18 type column with size $2.1 \times 100 \mathrm{~mm}$ and column temperature $33^{\circ} \mathrm{C}$ (Boelan and Purnomo 2019). 


\section{RESULTS AND DISCUSSION}

\section{Biodecolorization MO by fungus}

The absorbance profile of MO during degradation by BRF D. dickinsii was shown in Figure 1. MO maximum wavelength was detected at $465 \mathrm{~nm}$, in which the absorbance of abiotic control and treatment by fungus was 3.424 and 1.109 respectively. These results showed that the decrease in the value of absorbance at $465 \mathrm{~nm}$ indicated of decolorization of MO by $D$. dickinsii. However, the peak of MO was shifted from $465 \mathrm{~nm}$ to $510 \mathrm{~nm}$ after incubation due to acidic conditions in culture that lead protonation process of $\mathrm{MO}$ and cause shifting the peak of the chromophore, thus change color from orange to red (Purnomo et al. 2019b). During pre-incubation, fungus produces some organic acids in which the $\mathrm{pH}$ culture was 1.9 .

Based on the absorbance result, \% decolorization was calculated, in which $D$. dickinsii decolorized MO approximately $68 \%$. The ability of $D$. dickinsii to degrade MO might be associated with the ability of this fungus to produce hydroxyl radicals generated by the Fenton reaction during the incubation (Purnomo et al. 2010). Besides, MO may also be degraded by extracellular enzymes, as some fungi produce some degradative enzymes, such as laccases and peroxidases (Singh et al. 2015). The more extracellular hydroxyl radicals and enzymes are produced during incubations (Kaneko et al. 2005), The highest decolorization was obtained.

\section{Biodecolorization MO by bacterium}

MO biodecolorization profile by bacteria was shown in Figure 2. The highest peak of MO decolorization by the bacterium was also obtained at $465 \mathrm{~nm}$. The MO decolorization by higher volume of bacteria resulted in decreasing of MO peak which indicating that MO was further decolorized. Azoic dye decolorization was occurred under anaerobic conditions by bacteria, which requires organic carbon as an energy source. Decolorization might be attributed to non-specific extracellular reactions occurring between reduced compounds generated by the anaerobic bacteria (Pandey et al. 2007). Table 1 provides the percentage of decolorization (\% decolorization) of the bacterium during degradation. The bacterium decolorized MO by approximately $50 \%, 90 \%, 91 \%, 91 \%$ and $92 \%$ at 2 , 4, 6, 8, dan $10 \mathrm{~mL}$ of bacteria in PDB medium, respectively. It showed that decolorization of MO was not significantly different in variation volume bacterium of 4$10 \mathrm{~mL}$ about $91 \%$, which indicated that higher amount of bacterium did not increase MO decolorization. The competition of bacteria for surviving might occur rather than to decolorize $\mathrm{MO}$, in which some toxic metabolites might be produced during stationary phase under abundant population of bacteria (Wahyuni et al. 2016).

\section{Biodecolorization MO by mixed cultures}

Figure 3 showed the profile of MO decolorization by mixed cultures, which MO peak decreased compared with abiotic control. This indicates that MO was decolorized and produced new peaks as metabolites around 300-450 nm.
The addition of all variations of bacteria showed increasing decolorization of MO.

Biodecolorization percentages of mixed cultures were shown in Table 1. As the volume of bacteria increases, the percentage of decolorization increases, except in the addition to $10 \mathrm{~mL}$ was decreased. Optimal decolorization has occurred in addition to bacteria of $4 \mathrm{~mL}$. On the other hand, the optimization ratio (OR) indicated the level of enhancement of MO degradation due to the synergistic relationship between $D$. dickinsii and $P$. aeruginosa, compared with the degradation by the individual organisms. The addition of $2 \mathrm{~mL}$ of $P$. aeruginosa showed the highest RO, which enhanced the degradation by approximately 2 times. The addition of $10 \mathrm{~mL}$ of $P$. aeruginosa showed the lowest RO. The optimal decolorization was obtained at mixed cultures of $D$. dickinsii with the additional of $4 \mathrm{~mL}$ of $P$. aeruginosa, thus the addition of bacteria $P$. aeruginosa into fungus $D$. dickinsii culture can increase the ability of decolorization by $34.24 \%$ (from $64.41 \%$ by $D$. dickinsii culture only to $98,65 \%$ by mixed cultures). Mixed microbial cultures have more power to degrade pollutants because they have more genetic information to produce complex enzymes and metabolites (Grizca and Setyo 2018).

\section{The identification of metabolites}

Based on characterization by LC-TOF/MS, four metabolites were detected at time retention $1.29 ; 2.27 ; 2.7$; 3.95; and 7.29 mins. Identification of metabolites was determined based on similarity between MS spectrum and time retention from database (Figure 4). The result of LC analysis showed that the mixed cultures were able to transform MO to some metabolites. Compared with control, MO was identified at time retention 7.29 mins, the MO peak was decreased compared with MO peak control. Based on TOF/MS data, the peak at retention time $1.29 \mathrm{~min}$ has $\mathrm{m} / \mathrm{z} 374$ which identified as 4-[N-(4-dimethylamino-3hydroxy-cyclohexa-2,5-dienylidene) hydrazino]-2-methoxy benzenesulfonic acid $\left(\mathrm{C}_{15} \mathrm{H}_{19} \mathrm{~N}_{3} \mathrm{O}_{5} \mathrm{~S}\right)$. The compound was reported previously which had fragments in $\mathrm{m} / \mathrm{z} 149$ in the form of compound $\mathrm{C}_{8} \mathrm{H}_{11} \mathrm{~N}_{3} \quad(\mathrm{~N}, \quad \mathrm{~N}$-dimethylamine fenildiazin), which is in accordance with previous research on the degradation of azo dyes by laccase enzyme from WRF, and there are m/z 118 fragments, $\mathrm{C}_{7} \mathrm{H}_{8} \mathrm{~N}_{2}$ was 4(methylamino) aniline) (Mishra et al. 2011).

At a peak of 2.27 mins, metabolite was identified as 4[N-(4-dimethylamino- 3-methoxy-cyclohexa-2,5dienylidene)-hydrazino]-2-methoxy-benzenesulfonic acid $\left(\mathrm{C}_{16} \mathrm{H}_{21} \mathrm{~N}_{3} \mathrm{O}_{5} \mathrm{~S}\right)$ with $\mathrm{m} / \mathrm{z}$ 338. This compound is supported by the presence of fragments in MS data with $\mathrm{m} / \mathrm{z} 213$ as $\mathrm{C}_{13} \mathrm{H}_{13} \mathrm{~N}_{3}$, fragment $\mathrm{m} / \mathrm{z} 137 \mathrm{C}_{8} \mathrm{H}_{12} \mathrm{~N}_{2}$ (1,4-diamine) in accordance with research on metabolites produced by Aeromonas sp. in MO (Du et al. 2015). The peak of 2.71 mins was identified as 4-[N-(4-dimethylamino-3,5dimethoxy-cyclohexa-2,5 -dienylidene)-hydrazino]-2methoxy-benzenesulfonic acid $\left(\mathrm{C}_{17} \mathrm{H}_{23} \mathrm{~N}_{3} \mathrm{O}_{6} \mathrm{~S}\right)$ with $\mathrm{m} / \mathrm{z}$ 434. This compound is supported by fragments $\mathrm{m} / \mathrm{z} 213$, $\mathrm{m} / \mathrm{z} 213$, and $\mathrm{m} / \mathrm{z} 152$. 
Table 1. Percentage of MO decolorization by bacteria culture (Pseudomonas aeruginosa) and mixed cultures (Daedalea dickinsii and $P$. aeruginosa)

\begin{tabular}{cccc}
\hline $\begin{array}{c}\text { Amount of } \\
\text { bacteria } \\
\text { culture }(\mathbf{m L})\end{array}$ & $\begin{array}{c}\text { \% } \text { \% MO Mo Decolorization } \\
\text { alone }\end{array}$ & $\begin{array}{c}\text { Mixed } \\
\text { cultures }\end{array}$ & $\begin{array}{c}\text { Optimizati } \\
\text { on Ratio }\end{array}$ \\
\cline { 2 - 3 } & $0 \pm 0.016$ & $0.00 \pm 0.017$ & \\
2 & $49.61 \pm 0.090^{\mathrm{a}}$ & $94.29 \pm 0.004^{\mathrm{a}}$ & $0.8^{\mathrm{a}}$ \\
4 & $90.28 \pm 0.040^{\mathrm{b}}$ & $97.99 \pm 0.011^{\mathrm{b}}$ & $0.62^{\mathrm{b}}$ \\
6 & $91.16 \pm 0.035^{\mathrm{b}}$ & $96.41 \pm 0.003^{\mathrm{c}}$ & $0.61^{\mathrm{b}}$ \\
8 & $91.41 \pm 0.029^{\mathrm{b}}$ & $92.26 \pm 0.015^{\mathrm{d}}$ & $0.58^{\mathrm{c}}$ \\
10 & $91.46 \pm 0.016^{\mathrm{b}}$ & $87.35 \pm 0.010^{\mathrm{e}}$ & $0.55^{\mathrm{c}}$ \\
\hline
\end{tabular}

Analyses were conducted by spectrophotometer UV-VIS. Data are mean \pm standard deviation $(\mathrm{n}=3)$. A $1 \mathrm{~mL}$ of bacteria $\approx 5.05 \times$ $10^{12} \mathrm{CFU}$. Data followed by the different minor letter on each column indicates significantly different $(P<0.05)$.

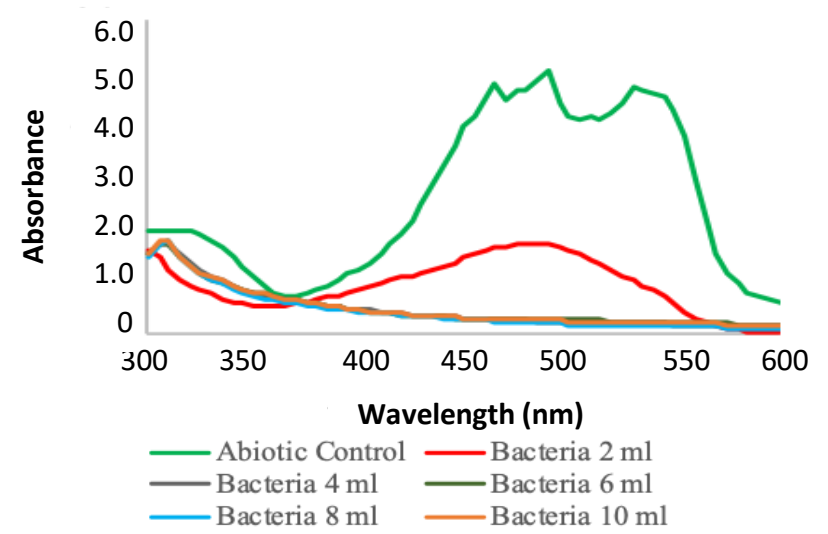

Figure 2. The profile of MO biodecolorization by bacteria cultures

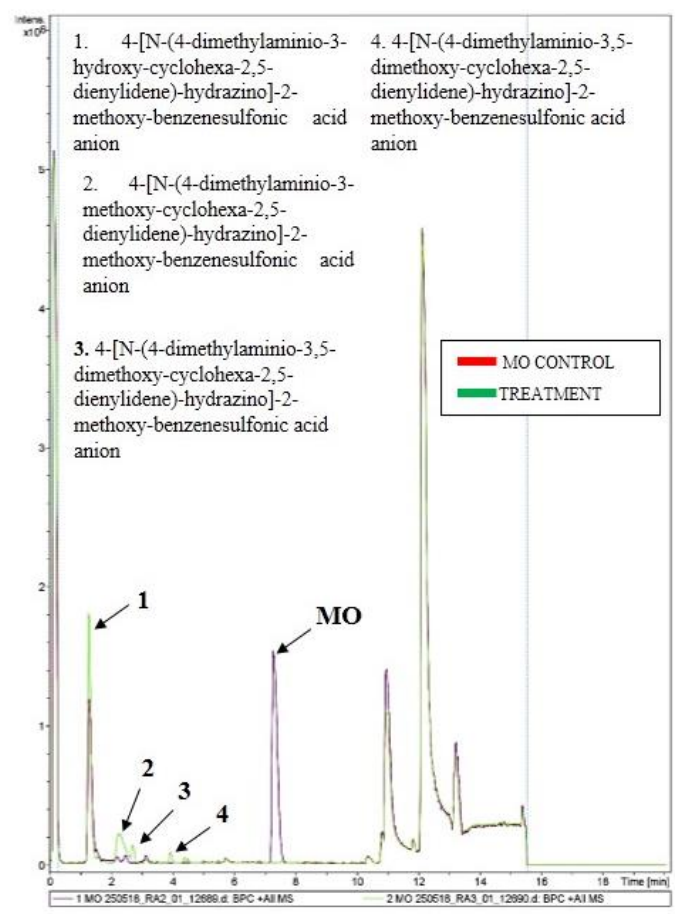

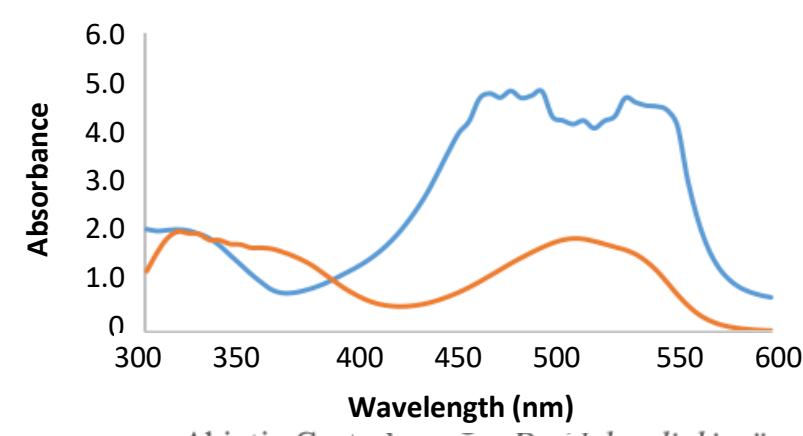

Abiotic Control

Figure 1. The profile of MO biodecolorization by Daedalea dickinsii

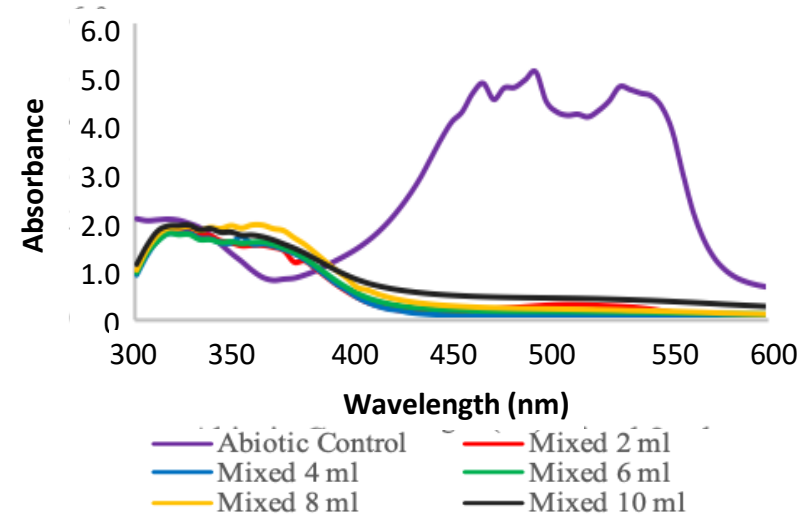

Figure 3. The profile of MO biodecolorization by mixed cultures<smiles>COc1cc(NN=C2C=CC(N(C)C)C(O)=C2)ccc1[N+](=O)[O-]</smiles>

$2 \mathrm{H}_{3} \mathrm{CO}$<smiles>COC1=CC(=NNc2ccc([N+](=O)[O-])c(OC)c2)C=CC1N(C)C</smiles><smiles>CCCCCCN(C)C1C(OC)=CC(=NNc2ccc([S+](=O)([O-])O)c(OC)c2)C=C1OC</smiles><smiles>COc1cc(NN=C2C=C(O)C(N(C)C)C(O)=C2)ccc1[O-]</smiles>

Figure 4. LC chromatogram of metabolite products of MO degradation by mixed cultures (red chromatogram is MO control; green chromatogram is treatment) 


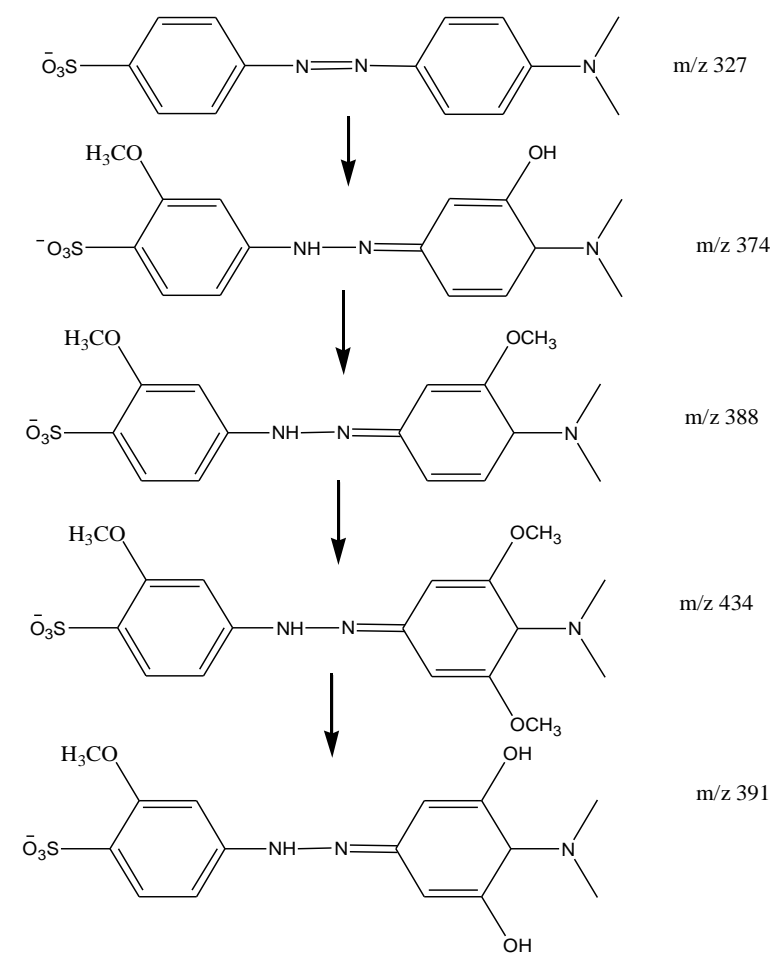

Figure 5. Proposed pathway degradation of MO by mixed cultures Daedalea dickinsii and Pseudomonas aeruginosa

The last metabolite was identified at 3.95 mins as $4-[\mathrm{N}-$ (4-dimethylamino- 3,5-dimethoxy-cyclohexa-2,5dienylidene)-hydrazino]-2-methoxy-benzenesulfonic acid $\left(\mathrm{C}_{15} \mathrm{H}_{19} \mathrm{~N}_{3} \mathrm{O}_{6} \mathrm{~S}\right)$ with $391 \mathrm{~m} / \mathrm{z}$. This compound is supported by fragments m/z 278 and fragments $\mathrm{m} / \mathrm{z} 171$ allowed the presence of compound $\mathrm{C}_{6} \mathrm{H}_{6} \mathrm{SNO}_{3}$ (4-sulfonic acid) (Hao et al. 2016). Based on the identification of metabolites, the MO decolorization pathway by mixed cultures of $D$. dickinsii and $P$. aeruginosa cultures were proposed in Figure 5.

The pathway of degradation starts from MO structure with $\mathrm{m} / \mathrm{z} 327$ and then MO had initial degradation in its benzene ring which begins to undergo the process of addition of the methylation and oxidation to form $4-[\mathrm{N}-(4-$ dimethylamino- 3-hydroxy-cyclohexa-2,5-dienylidene)hydrazino]-2 methoxy benzenesulfonic acid with $\mathrm{m} / \mathrm{z} 374$ with additional functional group. After that changed, the alcohol functional group become methoxy and forming 4[N-(4-dimethylamino- 3-methoxy-cyclohexa-2,5dienylidene)-hydrazino]-2-methoxy-benzenesulfonic acid $\left(\mathrm{C}_{16} \mathrm{H}_{21} \mathrm{~N}_{3} \mathrm{O}_{5} \mathrm{~S}\right)$ with $\mathrm{m} / \mathrm{z} 338$. The $\mathrm{MO}$ structure becomes bulkier with the change on its benzene ring with increasing polarity and affinities of its structure. The last form 4-[N(4-dimethylamino- 3,5-dimethoxy-cyclohexa-2,5dienylidene)-hydrazino]-2-methoxy-benzenesulfonic acid $\left(\mathrm{C}_{15} \mathrm{H}_{19} \mathrm{~N}_{3} \mathrm{O}_{6} \mathrm{~S}\right)$ with $391 \mathrm{~m} / \mathrm{z}$ as results of the degradation pathway.

\section{ACKNOWLEDGEMENTS}

This study was supported by a grant from research project from the Directorate of Research and Community Service, Directorate General of Strengthening Research and Development, Ministry of Research, Technology and Higher Education No. 5/E1/KP.PTNBH/2019.

\section{REFERENCES}

El Nemr A. 2012. Non-Conventional Textile Waste Water Treatment. In: Nemr AE (ed) Nova Science Publishers, Inc., New York.

Ali N, Hameed A, Ahmed S. 2010. Role of brown-rot fungi in the bioremoval of azo dyes under different conditions. Braz J Microbiol 41 (4): 907-915.

Boelan EG, Purnomo AS. 2019. Biodegradation of 1,1,1-trichloro-2,2-bis (4-chlorophenyl) ethane (DDT) by mixed cultures of white-rot fungus Ganoderma lingzhi and bacterium Pseudomonas aeruginosa. Hayati J Biosci 26: 90-95.

Bumpus JA. 2004. Biodegradation of azo dyes by fungi. In: Arora DK (ed.). Fungal Biotechnology in Agricultural, Food, and Environmental Applications. Marcel Dekker, New York.

Chiong T, Laua SY, Hong Z, Koha BY, Danquaha MK. 2016. Enzymatic treatment of methyl orange dye in synthetic wastewater by plantbased peroxidase enzymes. J Environ Chem Eng 4 (2): 2500-2509.

Du LN, Li G, Zhao YH, Xu HK, Wang Y, Zhou Y, Wang L. 2015. Efficient metabolism of the azo dye methyl orange by Aeromonas sp. strain DH-6: Characteristics and partial mechanism. Intl Biodet Biodeg 105: 66-72.

Grizca BE, Setyo PA. 2018. Abilities of co-cultures of white-rot fungus Ganoderma lingzhi and bacteria Bacillus subtilis on biodegradation DDT. J Physics: Conf Ser 1095: 102015. DOI: 10.1007/s13762-01902484-3. 
Hao J, Yabing S, Jingwei F, Jian W. 2016. Heterogeneous electro-Fenton oxidation of azo dye methyl orange catalyzed by magnetic $\mathrm{Fe}_{3} \mathrm{O}_{4}$ nanoparticles. Water Sci Technol 74 (5): 1116-1126.

Kaneko S, Yoshitake K, Itakura S, Tanaka H, Enoki A. 2005. Relationship between production of hydroxy radicals and degradation of wood, crystalline cellulose, and a lignin related compound or accumulation of oxalic acid in cultures of brown rot fungi. J Wood Sci 51: 262-269.

Kuppusamy S, Sethurajan M, Kadarkarai M, Aruliah R. 2017. Biodecolourization of textile dyes by novel, indigenous Pseudomonas stutzeri MN1, and Acinetobacter baumannii MN3. J Environ Chem Eng 5 (1): 716-724

Liu Q, Zheng Z, Yang X, Luo X, Zhang J, Zheng B. 2012. Effect of factors on decolorization of azo dye methyl orange by oxone/natural sunlight in aqueous solution. Environ Sci Pollut Res 19 (2): 577-584.

Ljubas D, Smoljanić G, Juretić H. 2015. Degradation of Methyl Orange and Congo Red dyes by using $\mathrm{TiO}_{2}$ nanoparticles activated by the solar and the solar-like radiation. J Environ Manag 161: 83-91.

Mishra A, Kumar S, Kumar PA. 2011. Laccase production and simultaneous decolorization of synthetic dyes in unique inexpensive medium by new isolates of white-rot fungus. Intl Biodet Biodeg 65 (3): 487-493

Pandey A, Singh P, Iyengar L. 2007. A Review: Bacterial decolorization and degradation of azo dyes. Intl Biodet Biodeg 59: 73-84

Purnomo AS, Koyama F, Mori T, Kondo R. 2010a. DDT degradation potential of cattle manure compost. Chemosphere 80: 619-624.

Purnomo AS, Mori T, Kamei I, Nishii T, Kondo R. 2010b. Application of mushroom waste medium from Pleurotus ostreatus for bioremediation of DDT-contaminated soil. Intl Biodet Biodeg 64: 397-402.

Purnomo AS, Kondo R, Mori T. 2010c. Involvement of Fenton reaction in DDT Degradation by Brown Rot Fungi. Intl Biodet Biodeg 64: 560565.

Purnomo AS, Mori T, Takagi K, Kondo R. 2011a. Bioremediation of DDT contaminated soil using brown-rot fungi. Intl Biodet Biodeg 65: 691-695.

Purnomo AS, Mori T, Kamei I, Kondo R. 2011b. Basic studies and applications on bioremediation of DDT: A review. Intl Biodet Biodeg 65: $921-930$

Purnomo AS, Mori T, Putra SR, Kondo R. 2013. Biotransformation of heptachlor and heptachlor epoxide by white-rot fungus Pleurotus ostreatus. Intl Biodet Biodeg 82: 40-44.

Purnomo AS, Putra SR, Shimizu K, Kondo R. 2014. Biodegradation of heptachlor and heptachlor epoxide-contaminated soils by white-rot fungal inocula. Environ Sci Pollut Res 21: 11305-11312.
Purnomo AS. 2017. Microbe-assisted degradation of aldrin and dieldrin. In: Singh SN (ed.). Microbe-Induced Degradation of Pesticides, $1^{\text {st }}$ ed. Springer Nature, Switzerland.

Purnomo AS, Nawfa R, Martak F, Shimizu K, Kamei I. 2017a. Biodegradation of aldrin and dieldrin by the white-rot fungus Pleurotus ostreatus. Curr Microbiol 74: 320-324.

Purnomo AS, Ashari K, Hermansyah F. 2017b. Evaluation of the synergistic effect of mixed cultures of white-rot fungus Pleurotus ostreatus and biosurfactant-producing bacteria on DDT biodegradation. J Microbiol Biotechnol 27: 1306-1315.

Purnomo AS, Maulianawati D, Kamei I. 2019a. Ralstonia pickettii Enhance the DDT Biodegradation by Pleurotus eryngii. J Microbiol Biotechnol 29: 1424-1433.

Purnomo AS, Mauliddawati VT, Khoirudin M, Nafwa R, Putra SR. 2019 b. Bio-decolorization and novel bio-transformation of methyl orange by brown-rot fungi. Intl J Environ Sci Tech 16: 7555-7564.

Rizqi HD, Purnomo AS. 2017. The ability of brown-rot fungus Daedalea dickinsii to decolorize and transform methylene blue dye. World $\mathbf{J}$ Microbiol Biotechnol 33 (5): 92. DOI: 10.1007/s11274-017-2256-z.

Sariwati A, Purnomo AS, Kamei I. 2017. Abilities of co-cultures of brown-rot fungus Fomitopsis pinicola and Bacillus subtilis on biodegradation DDT. Curr Microbiol 74: 1068-1069.

Sariwati A, Purnomo AS. 2018. The effect of Pseudomonas aeruginosa addition on 1,1,1 Trichloro 2,2 bis (4 chlorophenyls) ethane DDT biodegradation by brown-rot fungus Fomitopsis pinicola. Indon $\mathrm{J}$ Chem 18: 75-81.

Setyo PA, Dwi RH, Sri F, Sulistyo PH, Ichiro K. 2018. Effects of bacterium Ralstonia pickettii addition on DDT biodegradation by Daedalea dickinsii. Res J Chem Environ 22: 151-156.

Sarayu K, Sandhya S. 2010. Aerobic biodegradation pathway for remazol orange by Pseudomonas aeruginosa. Appl Biochem Biotechnol 160 (4): 1241-1253.

Singh RL, Singh PK, Singh RP. 2015. Enzymatic decolorization and degradation of azo dyes-A review. Intl Biodet Biodeg 104: 21-31.

Wahyuni S, Suhartono MT, Khaeruni A, Purnomo AS, Asranudin, Holilah, Riupassa PA. 2016. Purification and characterization of thermostable chitinase from Bacillus SW42 for chitin oligomer production. Asian J Chem 28: 2731-2736.

Wahyuni S, Khaeruni A, Purnomo AS, Asranudin, Holilah, Fatahu. 2017. Characterization of mannanase isolated from corncob waste bacteria. Asian J Chem 29: 1119-1120. 